\title{
Precipitation Controls on Soil Biogeochemical and Microbial Community Composition in Rainfed Agricultural Systems in Tropical Drylands
}

\author{
Thalita F. Abbruzzini 1,2, Morena Avitia 1 ${ }^{1}$, Karen Carrasco-Espinosa ${ }^{1}$, Víctor Peña ${ }^{1}$, Alberto Barrón-Sandoval ${ }^{1}$, \\ Ulises Isaac Salazar Cabrera ${ }^{1}$, Rocío Cruz-Ortega ${ }^{1}$, Mariana Benítez ${ }^{1}$, Ana E. Escalante ${ }^{1}$, Julieta A. Rosell ${ }^{1}$ (D, \\ Ana Wegier ${ }^{3} \mathbb{D}$ and Julio Campo ${ }^{1, * \mathbb{D}}$
}

check for

updates

Citation: Abbruzzini, T.F.; Avitia, M.;

Carrasco-Espinosa, K.; Peña, V.;

Barrón-Sandoval, A.; Salazar Cabrera,

U.I.; Cruz-Ortega, R.; Benítez, M.;

Escalante, A.E.; Rosell, J.A.; et al.

Precipitation Controls on Soil

Biogeochemical and Microbial

Community Composition in Rainfed

Agricultural Systems in Tropical

Drylands. Sustainability 2021, 13,

11848. https://doi.org/10.3390/

su132111848

Academic Editor: Thierry Becquer

Received: 19 July 2021

Accepted: 29 September 2021

Published: 27 October 2021

Publisher's Note: MDPI stays neutral with regard to jurisdictional claims in published maps and institutional affiliations.

Copyright: (C) 2021 by the authors Licensee MDPI, Basel, Switzerland. This article is an open access article distributed under the terms and conditions of the Creative Commons Attribution (CC BY) license (https:/ / creativecommons.org/licenses/by/ $4.0 /)$.
1 Instituto de Ecología, Universidad Nacional Autónoma de México, Mexico 04510, Mexico; thalita@geologia.unam.mx (T.F.A.); morena.avitia@iecologia.unam.mx (M.A.); karen@iibiomedicas.unam.mx (K.C.-E.); victorp29@yahoo.com.mx (V.P.); abarrons@uci.edu (A.B.-S.); biouisc92@gmail.com (U.I.S.C.); rcruz@ecologia.unam.mx (R.C.-O.); mbenitez@iecologia.unam.mx (M.B.); aescalante@iecologia.unam.mx (A.E.E.); julieta.rosell@iecologia.unam.mx (J.A.R.)

2 Instituto de Geología, Universidad Nacional Autónoma de México, Mexico 04510, Mexico

3 Instituto de Biología, Universidad Nacional Autónoma de México, Mexico 04510, Mexico; awegier@ib.unam.mx

* Correspondence: jcampo@ecologia.unam.mx

Abstract: The current and expected expansion of agriculture in the drylands of Mexico, together with the decrease in precipitation occurring in the country, likely affect ecosystem processes and will bring great challenges for the suitability of rainfed agriculture for smallholder farmers. Here, we assessed metrics of the soil C, N, and P cycles, as well as soil microbial diversity, under rainfed maize and common bean cropping in arid and semiarid regions of central Mexico. The soil enzymatic vector angles of cultivated plots in both regions were above $45^{\circ}$, suggesting P limitation for microbial growth and crop productivity. Although changes were not observed in the intensity of this P-limitation with aridity, we found a negative effect of drought increase on the concentration of soil organic $\mathrm{C}$ and total $\mathrm{N}$, with consequences for the $\mathrm{C}, \mathrm{N}$, and $\mathrm{P}$ balance in soils. Increasing aridity leads to the homogenization of microbial diversity. Considering a scenario in which decreases in mean annual precipitation would uncouple the biogeochemical cycles and homogenize soil biodiversity, the ecological implications could be an increase in the vulnerability of agricultural ecosystems to drought, with negative consequences for the suitability of rainfed agriculture in the drylands of central Mexico.

Keywords: climate change; drought; enzyme stoichiometry; smallholder farming; soil biogeochemistry

\section{Introduction}

Nearly $75 \%$ of the agricultural production in rural Mexico is rainfed. This type of agriculture has seen rapid growth since the late 1980s [1], especially due to the expansion of maize and common bean cropping in the semiarid and arid regions of the country. Given its reliance on precipitation, this kind of agriculture is highly vulnerable to climate variability and climate change [2,3]. Substantial precipitation decreases in Mexican semiarid lands have been observed over the past 30 years [4], putting this agriculture under severe threat. Precipitation variability does not only affect plant growth in the current year; it may also have a strong effect on long-term food yields, considering the central role of precipitation in biogeochemical cycling and carbon (C) sequestration in agricultural soils [5,6]. Although many measures have been suggested to reduce the vulnerability of smallholder farmers to climate change at a global scale [7], regional diagnoses of the effect of changes in 
precipitation patterns on soil fertility are still lacking and are crucial for adaptation to climate change in rainfed agricultural fields $[8,9]$.

While rainfed agriculture is widespread in the tropics, there are few reports on how soil function in agroecosystems changes as drought intensity and frequency increase [10-12], and none of these reports is focused on maize and common bean rainfed agroecosystems. Moreover, the effects of aridity on soil bacterial and fungi diversity and community composition in rainfed agriculture are not well documented in semiarid and arid tropical regions, despite the crucial role of microbes in reducing the impact of drought on plant performance and crop yields $[12,13]$. Thus, understanding the effects of drought on soil function, in combination with soil microbial activity, is crucial for better management of agricultural soils and for designing adaptative strategies to climate change. Climate models predict that by the end of the 21st century, central Mexico will experience long-term precipitation decreases of around 25\% [14], and this precipitation shift could have significant effects on the biogeochemistry of rainfed agriculture, especially in arid and semiarid regions. Given this difficult scenario, in this study, we aimed to identify differences in soil biogeochemistry in arid areas under rainfed agriculture. For this purpose, we selected two arid areas with different amounts of mean annual precipitation (554 and $416 \mathrm{~mm}$ of mean annual precipitation; MAP) that are representative of the agricultural areas in Mexico.

The reduction of soil fertility is one of the most acute problems that tropical rainfed agriculture faces. This loss is closely associated with the disturbance of natural biogeochemical cycles in soils. Although limitations of net primary productivity in terrestrial ecosystems are multielement in nature [15], phosphorus $(\mathrm{P})$ often limits plant growth in tropical regions [16], including agricultural ones [17]. This limitation is the result of low amounts of total $\mathrm{P}$ in the system, or because $\mathrm{P}$ is present in forms that are not available to plants. Phosphorus limitation is pervasive in tropical areas with drought $[18,19]$, as well as in semiarid and arid regions, due to reduced diffusion of nutrients into the soil solution [20]. Moreover, the export of $\mathrm{P}$ due to harvesting tends to increase soil $\mathrm{P}$ limitation in agricultural ecosystems, with $30 \%$ of the global crop area showing a P deficit [21]. Phosphorus deficit also impacts agricultural soils through its negative effect on the growth of soil microbial biomass, i.e., one of the main drivers of soil function [22]. Different studies have been conducted on the effects of $\mathrm{P}$ limitation on microorganisms in native $[23,24]$ and agricultural tropical soils [25]. Direct evidence indicates that $P$ addition causes an increase in soil microbial nutrient immobilization, but also a decrease in soil phosphatase activity $[24,26]$. Therefore, as is also the case for plants, the level of a single nutrient can be the rate-limiting factor for microbial processes at the ecosystem scale $[27,28]$.

Microbial nutrient limitations can be investigated by measuring potential exoenzymatic activity. This efficient method has been proposed as a means of inferring nutrient limitations for heterotrophic soil microorganisms [29]. Enzymes are considered to be particularly relevant, as they catalyze the rate-limiting step of decomposition and nutrient mineralization $[30,31]$. It is suggested that the production of enzymes targeting different nutrient resources reflects the metabolic and stoichiometric requirements of soil microorganisms [29]. However, microbial biomass carbon:nitrogen:phosphorus (C:N:P) ratios are relatively invariant across ecosystems [30], differences in microorganisms' efforts to acquire $\mathrm{C}, \mathrm{N}$, and $\mathrm{P}$ should be expected among ecosystems that differ in nutrient quantity as well as quality, for microorganisms to maintain homeostasis. Therefore, high enzyme activity targeting a particular resource is thought to indicate nutrient limitation by that resource, and ratios of $\mathrm{C}_{-}, \mathrm{N}-$-, and P-acquiring enzyme activity to the activity of enzymes targeting other resources should reflect relative nutrient availability and, thus, limiting factors for microorganisms [29].

Here, we examine the diversity and composition of soil microbial communities in traditional cropping systems with maize and common bean, two staple crops for human diet and nutrition worldwide [32], with the goal of contributing to a better understanding of the relationship between microbial communities, soil nutrient cycling, and drought. We carried out these analyses in maize-bean agroecosystems in an arid and a semiarid 
region in Mexico. The semiarid region has precipitation rates similar to those of many parts of Mexico [4], and the arid region has precipitation rates comparable to those projected to occur over the next century [33]. Based on measurements of organic $C$ and total $\mathrm{N}$ and $\mathrm{P}$ soil concentrations, enzymes used to infer growth-limiting nutrients, and soil microorganism DNA was examined to assess how aridity alters belowground processes controlling soil microbial composition and biogeochemical heterogeneity. Specifically, we explored: (i) the links between soil and crop characteristics across regions, (ii) the potential nutrient and/or carbon limitation of microbial activity, and (iii) the relationships among precipitation regime, soil characteristics, and microbial composition. Finally, using data of plant productivity and leaf and root nutrient concentrations in studied crops we discussed the variation in soil-plant relationship across regions. One advantage of this study system was that potential differences in soil biogeochemical cycles and microbial community composition due to air temperature, chemical fertilization, and cropping systems were excluded, as the selected plots of the two regions have minimal differences in these climatic characteristics and crop management.

\section{Materials and Methods}

\subsection{Study Sites}

The study sites are located in the central highlands of Mexico in the state of Guanajuato. Two locations were selected to provide data on an arid region and a semiarid region, as per aridity indices [34]. The arid sites are in the municipality of San Felipe $\left(21^{\circ} 29^{\prime} 00^{\prime \prime} \mathrm{N}\right.$, $\left.101^{\circ} 13^{\prime} 00^{\prime \prime} \mathrm{W}\right)$ and the semiarid ones are in Guarapo $\left(20^{\circ} 23^{\prime} 03^{\prime \prime} \mathrm{N}, 101^{\circ} 24^{\prime} 38^{\prime \prime} \mathrm{W}\right)$. Multiple representative sites of rainfed maize (Zea mays L., Mexican landrace) $(n=5)$ and common bean (Phaseolus vulgaris L., 'Flor de junio' cultivar) $(n=4)$ cropping were selected. The two locations are $140 \mathrm{~km}$ apart from each other. Despite their similar precipitation distributions throughout the year (i.e., with a rainy season from June to September that concentrates $\sim 60 \%$ of total annual precipitation; [35]), they differ in rainfall regimen and aridity (by $33 \%$ in the case of mean annual precipitation; and by $67 \%$ in the case of aridity) (Table 1 ). The soils generally fall into two groups, Inceptisols, and Entisols, and vary from medium to shallow depths. The time of cropping (ranging from 30 to 40 years) does not vary across regions, and the range of the annual fertilization rates is similar at arid and semiarid locations (40-50 kg of $\mathrm{N}$ and 5 to $7 \mathrm{~kg}$ of $\mathrm{P}$ per hectare). Dry fertilizers (urea, consisting of $\left(\mathrm{NH}_{2}\right)_{2} \mathrm{CO}$, or triple superphosphate, consisting of $\left.\mathrm{Ca}\left(\mathrm{H}_{2} \mathrm{PO}_{4}\right)_{2} \cdot \mathrm{H}_{2} \mathrm{O}\right)$ are applied by hand, as appropriate. The sowing and harvest dates for both crops are May and November, respectively, in the case of maize, and May and September in the case of common bean; the sowing of both crops is two weeks before in the semiarid site than in the arid counterpart. Despite the differences in precipitation regimen between locations, the yields of both maize and common bean do not vary between regions (Table 1 ).

Maize crops cover 7.76 million hectares of Mexico and represent $14.5 \%$ of the national agriculture gross domestic product (GDP) [36]. On the other hand, the common bean covers 1.63 million hectares and represents $1.93 \%$ of the national agriculture GDP in the country [37]. The yield of both crops should increase in the period 2016 to 2030 (by 4.0\% per year in the case of maize, and by $5.7 \%$ per year in the case of common bean) to satisfy the expected increase in demand [36,37].

The state of Guanajuato is one of the largest producers of maize and common bean in the country. The southern half of the state contains extensive and fertile plains of the El Bajio ecoregion (semiarid climate), located in the trans-volcanic Mexican belt, and the northern plain is part of the Sierras y Altiplanicie de Mesa Central ecoregion (arid climate), located in drylands of central Mexico. Despite its importance for the Mexican agricultural sector, the current and expected expansion of rainfed agriculture, together with the expected decrease in precipitation amount, are likely to have strong effects on soil processes and will bring great challenges for the suitability of rainfed agriculture in these regions. 
Table 1. General characteristics of arid and semiarid sites and crops.

\begin{tabular}{|c|c|c|}
\hline Site Characteristics & Arid Region & Semiarid Region \\
\hline \multicolumn{3}{|l|}{ Climate $^{\dagger}$} \\
\hline Mean annual precipitation (MAP, $\mathrm{mm} \mathrm{yr}^{-1}$ ) & 416 & 554 \\
\hline Mean annual temperature $\left(\mathrm{MAT},{ }^{\circ} \mathrm{C}\right)$ & 18.1 & 18.9 \\
\hline Potential evapotranspiration (PE, $\mathrm{mm} \mathrm{yr}^{-1}$ ) & 2350 & 1832 \\
\hline Aridity index (MAP/PE ratio) & 0.18 & 0.30 \\
\hline $\begin{array}{l}\text { Mean monthly precipitation during the growing season of } \\
\text { maize }\left(\mathrm{mm} \mathrm{month}^{-1}\right)\end{array}$ & $52 \pm 10$ & $72 \pm 20$ \\
\hline $\begin{array}{l}\text { Mean monthly precipitation during the growing season of } \\
\left.\text { common bean (mm month }{ }^{-1}\right)\end{array}$ & $65 \pm 8$ & $94 \pm 12$ \\
\hline $\begin{array}{l}\text { Mean monthly temperature during the growing season of } \\
\text { maize }\left({ }^{\circ} \mathrm{C} \text { month }^{-1}\right)\end{array}$ & $19.4 \pm 1.0$ & $20.1 \pm 1.2$ \\
\hline $\begin{array}{l}\text { Mean monthly temperature during the growing season of } \\
\text { common bean }\left({ }^{\circ} \mathrm{C} \text { month }^{-1}\right)\end{array}$ & $20.3 \pm 0.5$ & $20.9 \pm 0.4$ \\
\hline \multicolumn{3}{|l|}{ Crop characteristics $\ddagger$} \\
\hline \multicolumn{3}{|l|}{ Grain yield $\left(\mathrm{Mg} \mathrm{ha}^{-1}\right)$} \\
\hline Maize & $1.17 \pm 0.17$ & $1.50 \pm 0.50$ \\
\hline Common bean & $0.28 \pm 0.06$ & $0.33 \pm 0.22$ \\
\hline \multicolumn{3}{|l|}{ Root biomass (g plant ${ }^{-1}$ ) } \\
\hline Maize & $24.7 \pm 3.3$ & $24.9 \pm 2.9$ \\
\hline Common bean & $1.54 \pm 0.2$ & $0.77 \pm 0.16$ \\
\hline \multicolumn{3}{|l|}{ Leaf $\mathrm{N}\left(\mathrm{mg} \mathrm{g}^{-1}\right)$} \\
\hline Maize & $17.9 \pm 2.4$ & $22.8 \pm 0.8$ \\
\hline Common bean & $39.5 \pm 1.5$ & $40.4 \pm 1.9$ \\
\hline \multicolumn{3}{|l|}{ Leaf $\mathrm{P}\left(\mathrm{mg} \mathrm{g}^{-1}\right)$} \\
\hline Maize & $2.3 \pm 0.5$ & $1.8 \pm 0.1$ \\
\hline Common bean & $2.7 \pm 0.2$ & $2.1 \pm 0.1$ \\
\hline \multicolumn{3}{|l|}{ Root N ( $\left.\mathrm{mg} \mathrm{g}^{-1}\right)$} \\
\hline Maize & $6.6 \pm 0.8$ & $9.3 \pm 0.2$ \\
\hline Common bean & $16.8 \pm 2.2$ & $15.6 \pm 1.2$ \\
\hline \multicolumn{3}{|l|}{ Root $\mathrm{P}\left(\mathrm{mg} \mathrm{g}^{-1}\right)$} \\
\hline Maize & $0.5 \pm 0.1$ & $0.5 \pm 0.04$ \\
\hline Common bean & $1.9 \pm 0.2$ & $1.2 \pm 0.2$ \\
\hline
\end{tabular}

Note. Values are mean \pm 1 SE. ${ }^{\dagger}$ Long-term climatic data (1980-2015) from National Commission of Water (CONAGUA) personal communication; $¥$ Julieta A. Rosell (unpublished data).

\subsection{Soil Sampling and Measurements}

Soil samples were collected in the middle of the rainy season (in August) to determine the effects of precipitation regimen on soil microbial diversity and community composition, and on soil $\mathrm{pH}$, organic $\mathrm{C}$, total $\mathrm{N}$, and total $\mathrm{P}$ in the $0-20 \mathrm{~cm}$ horizon. At each plot, three equidistant lines (separated by $20 \mathrm{~m}$ ) were drawn and three soil cores, $7.5 \mathrm{~cm}$ in diameter and $20 \mathrm{~cm}$ deep, were taken from three equidistant points (separated by $20 \mathrm{~m}$ ) along each line. The nine cores ( 3 samples $\times 3$ lines) were combined into one composite sample per plot. In agricultural soils, nutrient availability and root uptake decline substantially below the plow layer [38] as a consequence of the upper $20 \mathrm{~cm}$ of soil containing a significant proportion of crop roots [39]. On the other hand, long-term trials have shown that fertilizers mainly affect nutrient availability in the plow layer, with very little impact on deeper soil layers [40]. At the study sites, the upper $20 \mathrm{~cm}$ of the soil profile in both regions concentrates soil organic matter, fine roots $(<1 \mathrm{~mm}$ in diameter), and nutrients (Víctor Peña, unpublished data).

The composite soil sample from each plot was sieved through a $2 \mathrm{~mm}$ mesh to remove plants, roots, and gravel and minimize the influence of plant residues on physical, chemical, and microorganism analyses. Samples were kept at $-20{ }^{\circ} \mathrm{C}$ prior to analysis. Soil $\mathrm{pH}$ was determined in a 1:2.5 soil to deionized water ratio using a glass electrode. Soil organic $C$ (OC) was analyzed in an automated C-analyzer after grinding a 5-g air-dried subsample was passed through a 100-mesh screen. Concentrations of total N (TN) and total P (TP) were 
determined using acid digestion in concentrated $\mathrm{H}_{2} \mathrm{SO}_{4}$ and analyzed in an automated NP-analyzer.

\subsection{Enzyme Analyses}

We measured the indicator enzymes most commonly used to infer growth-limiting nutrients, i.e., B-1,4-glucosidase (BG; enzyme commission number: EC 3.2.1.21) and polyphenol oxidase (POX; EC 1.10.3.1) to infer C-acquiring enzymes, leucine aminopeptidase (LAP; EC 3.4.11.1), ß-1,4-N-acetylglucosaminidase (NAG; EC 3.2.1.14) to infer N-acquiring enzymes [29], following the method proposed by Jackson et al. [41]. The enzyme assays were incubated at $25^{\circ} \mathrm{C}$ for $2 \mathrm{~h}$ and their absorbance was recorded using a microplate reader at $410 \mathrm{~nm}$ for BG, LAP, NAG, and AP activities, and at $460 \mathrm{~nm}$ for POX activity. The concentration of pNP (or tyrosine, for POX) detected in the soil sample was corrected by subtracting the sum of absorption from the sample and substrate control wells, and enzyme activities were calculated as follows:

$$
\mathrm{EA}=(\text { final absorbance }) /(\mathrm{C} \times \text { incubation time } \times \text { soil dry mass }) ;
$$

where EA is the enzyme activity expressed in $\mu \mathrm{mol}$ of $\mathrm{pNP}$ (or tyrosine, for polyphenol oxidase) released per gram of soil per hour $\left(\mu \mathrm{mol} \mathrm{g}^{-1}\right.$ hour $\left.^{-1}\right)$; and $C$ is the conversion factor that relates absorbance to $\mu \mathrm{mol}$ of $\mathrm{pNP}$ (or tyrosine, for polyphenol oxidase) in each enzyme activity.

The relationships between relative enzyme activities for $\mathrm{C}$ vs. N, (BG + POX/LAP + NAG), $\mathrm{C}$ vs. $\mathrm{P}(\mathrm{BG}+\mathrm{POX} / \mathrm{AP})$, and $\mathrm{N}$ vs. $\mathrm{P}(\mathrm{LAP}+\mathrm{NAG} / \mathrm{AP})$ were calculated [29]. Moreover, a quantitative method to interpret simultaneous microbial $C, N$, and $P$ acquisition through the activities of these key extracellular enzymes was applied, as proposed by Moorhead et al. [42]. The method is based on the calculation of two vector components, length and angle, created by plotting the proportional C:N vs. C:P ratios of enzyme activity, to quantify relative investments in $\mathrm{C}$ vs. nutrient (i.e., $\mathrm{N}$ or $\mathrm{P}$ ) acquisition (vector length) and $\mathrm{P}$ vs. $\mathrm{N}$ acquisition (vector angle).

\subsection{DNA Extraction and Sequencing}

Microbial DNA was extracted from $0.5 \mathrm{~g}$ of soil from each plot by triplicate, using the MoBio Power Soil DNA commercial kit (MoBio Laboratories, Solana Beach, CA, USA) in accordance with the manufacturer's instructions. The bacterial 16S rRNA gene (V1V2 hypervariable regions) and fungal ITS regions were amplified and sequenced with 27F/388R primers [43] and ITS1F/ITS2aR primers [44,45], respectively, using an Illumina MiSeq at the Research and Testing Laboratory (Lubbock, TX, USA).

\subsection{Data Analysis}

Mean values per region and per cropping system were calculated for soil clay content, $\mathrm{pH}$, organic $\mathrm{C}$, total $\mathrm{N}$, total $\mathrm{P}$, enzyme data (the activity of $B$-glucosidase, polyphenol oxidase, $\mathrm{B}-1,4-\mathrm{N}$-acetylglucosaminidase, leucine aminopeptidase and phosphatase, and enzyme activity ratios), and microbial diversity data (Shannon and Simpson indexes), and these values were used for statistical analyses. To investigate crop changes in soil element concentrations and enzymes activities under crops over both regions, a leastsquares linear model was adjusted and a two-way analysis of variance (ANOVA) was performed considering crop and region, and their interaction. The residuals were explored for normality and variance homogeneity using the Shapiro-Wilk's test and Levene's test, respectively. Data were transformed logarithmically when the assumptions of normality and homoscedasticity did not occur. Principal component analysis and Pearson correlation coefficients were performed to examine the relationships among soil biogeochemical and microbiological metrics in both regions.

Illumina raw sequences were processed using the Quantitative Insights into Microbial Ecology 2 pipeline (QIIME2) [46] with default arguments, except on the quality filter, where sequences with more than 2 N's were removed [47]. Operational Taxonomic Units (OTUs) 
were clustered with a 97\% similarity cutoff using VSEARCH [48]. Taxonomic assignment of representative OTUs was performed with the Greengenes DataBase (v 13.8); [49] for the 16s RNA gene, and with the UNITE DataBase for the ITS region. Shannon and Simpson diversity indices were calculated to estimate diversity from the OTU derived using the bioinformatic procedure of the "phyloseq" R package [50]. Relative abundance of microbial groups was estimated for each crop in each region and a generalized linear model (GLM) was adjusted with a binomial distribution, a two-way Analysis of Deviance (ANODEV) was performed considering crop and region and their interaction, and the inferences were made based on the Wald's test, following the standard procedures presented by McCullagh and Nelder [51]. The summary of the variance components can be found in the supplementary information (Tables S1-S6). All statistical analyses were performed using the R Version 3.6.1 [52] and the "emmeans" package [53].

\section{Results}

\subsection{Soil $\mathrm{pH}$ and Biogeochemical Properties}

The soil $\mathrm{pH}$ did not change across regions or crops $(p>0.05)(6.4 \pm 0.16$; mean \pm 1 $\mathrm{SE}$ for all samples). Consistently, soil organic $\mathrm{C}$ and total $\mathrm{N}$ concentrations decreased with a decrease in precipitation amount (Table 2; $p<0.01$, for organic $C$, and $p=0.04$, for total N, Table S1). However, differences in soil total $\mathrm{P}$ between regions were low and nonsignificant ( $p=0.55$, Table S1). Soil C:N ratios were low (ranging from 6 to 10), reflecting $\mathrm{N}$ accumulation in the soil by fertilization and decreased with aridity (from 8.2 on average in the case of the semiarid region to 6.4 in the case of the arid region). Similarly, C:P and $\mathrm{N}: \mathrm{P}$ ratios showed an abrupt decrease with aridity (from 51 to 34 and 6.5 to 5.2 for the C:P and N:P ratios, respectively). Soil organic $\mathrm{C}$ and, total $\mathrm{N}$ and $\mathrm{P}$ concentrations did not vary between crops (i.e., maize and common bean crops) (Table 2; $p=0.05$ to 0.60, Table S1).

Table 2. Organic carbon, total nitrogen, and total phosphorus concentrations in topsoil $(0-20 \mathrm{~cm}$ in depth) under different cropping systems in arid and semiarid regions.

\begin{tabular}{|c|c|c|c|c|}
\hline \multirow[t]{2}{*}{ Crop } & \multirow[t]{2}{*}{ Region } & \multirow[t]{2}{*}{ Organic C } & Total N & Total P \\
\hline & & & $\left(\mathrm{mg} \mathrm{g}^{-1}\right)$ & $\left(\mu g^{-1}\right)$ \\
\hline \multirow[t]{2}{*}{ Maize } & Arid & $11.70 \mathrm{Ba} \pm 0.52$ & $1.65 \mathrm{Aa} \pm 0.36$ & $340 \mathrm{Aa} \pm 73$ \\
\hline & Semiarid & $22.23 \mathrm{Aa} \pm 0.75$ & $2.27 \mathrm{Aa} \pm 0.57$ & $415 \mathrm{Aa} \pm 93$ \\
\hline \multirow[t]{2}{*}{ Common bean } & Arid & $11.48 \mathrm{Ba} \pm 0.61$ & $1.99 \mathrm{Ba} \pm 0.40$ & $330 \mathrm{Aa} \pm 81$ \\
\hline & Semiarid & $19.37 \mathrm{Ab} \pm 0.91$ & $2.97 \mathrm{Aa} \pm 0.71$ & $396 \mathrm{Aa} \pm 98$ \\
\hline
\end{tabular}

Note. Values are means \pm 1 SE ( $n=5$ for maize and $n=4$ for common bean crops). Different capital letters indicate means are significantly different $(p<0.05)$, when testing for differences between regions within a crop. Different lowercase letters indicate means are significantly different $(p<0.05)$, when testing for differences between crops within a region.

Extracellular enzyme activity in soils under maize crop and common bean crop is shown in Table 3. We found an increasing gradient of enzyme activity in the direction of NAG $<$ LAP $<$ POX $\sim$ BG $<$ AP. The corresponding ANOVA indicated that at least one enzymatic level differs from the rest $(p<0.001)$ and paired comparisons using the Tukey-Kramer HSD test showed that enzymes of the $\mathrm{N}$ cycle sustained lower levels of activity $(p<0.05$ in all cases), while those of the P cycle were the most active $(p<0.05$ in all cases). Enzymes of the $\mathrm{C}$ cycle had intermediate levels of activity $(p>0.05)$. 
Table 3. 8 -1,4-glucosidase, polyphenol oxidase, leucine aminopeptidase, $B-1,4-N$-acetylglucosaminidase and acid phosphatase activities in topsoil (0-20 cm in depth) under different cropping systems in arid and semiarid regions.

\begin{tabular}{|c|c|c|c|c|c|c|}
\hline Crop & Region & BG & POX & LAP & NAG & $\mathbf{A P}$ \\
\hline & & ( $\mu \mathrm{mol}$ pNP) & ( $\mu$ mol tyrosine) & $\begin{array}{c}\text { ( } \mu \text { mol pNP g } \\
\text { soil }^{-1} \text { hour }^{-1} \text { ) }\end{array}$ & (g soil $^{-1}$ hour $^{-1}$ ) & (g soil $^{-1}$ hour $\left.^{-1}\right)$ \\
\hline \multirow[t]{2}{*}{ Maize } & Arid & $0.339 \mathrm{Aa} \pm 0.014$ & $0.295 \mathrm{Aa} \pm 0.021$ & $0.168 \mathrm{Aa} \pm 0.008$ & $0.158 \mathrm{Aa} \pm 0.014$ & $0.679 \mathrm{Aa} \pm 0.077$ \\
\hline & Semiarid & $0.373 \mathrm{Aa} \pm 0.019$ & $0.318 \mathrm{Aa} \pm 0.022$ & $0.139 \mathrm{Aa} \pm 0.009$ & $0.129 \mathrm{Aa} \pm 0.017$ & $0.701 \mathrm{Aa} \pm 0.074$ \\
\hline \multirow[t]{2}{*}{ Common bean } & Arid & $0.342 \mathrm{Aa} \pm 0.017$ & $0.322 \mathrm{Aa} \pm 0.025$ & $0.214 \mathrm{Aa} \pm 0.009$ & $0.138 \mathrm{Aa} \pm 0.015$ & $0.638 \mathrm{Aa} \pm 0.050$ \\
\hline & Semiarid & $0.251 \mathrm{Aa} \pm 0.021$ & $0.237 \mathrm{Aa} \pm 0.026$ & $0.184 \mathrm{Aa} \pm 0.011$ & $0.126 \mathrm{Aa} \pm 0.017$ & $0.580 \mathrm{Aa} \pm 0.078$ \\
\hline
\end{tabular}

Note. Values are means $\pm 1 \mathrm{SE}$ ( $n=5$ for maize and $n=4$ for common bean crops). Abbreviations: AP, acid phosphatase; BG, $B-1,4-$ glucosidase; LAP, leucine aminopeptidase; NAG, B-1,4-N-acetylglucosaminidase; POX, polyphenol oxidase. Different capital letters indicate means are significantly different $(p<0.05)$ when testing for differences between regions within a crop. Different lowercase letters indicate means are significantly different $(p<0.05)$ when testing for differences between crops within a region.

No significant changes in $\beta$-1,4-glucosidase and soil $\mathrm{N}$ and $\mathrm{P}$ enzyme activities were detected between regions or crops (Table 3; region effect, $p=0.10$ to 0.35 ; crop effect, $p=0.55$ to 0.89 , Table S2). In contrast, the activity of POX across crops varied as a function of region (crop*region effect, $p=0.04$, Table S2). In addition, there were no significant regional or crop effects on C:P and N:P enzyme activity ratios in soils (Table 4; region effect, $p=0.74$ and 0.64 , respectively; crop effect, $p=0.89$ and 0.68 , respectively, Table S3). In contrast, the enzyme activity ratio for $\mathrm{C}: \mathrm{N}$ under each crop varied as function of region (crop*region effect, $p=0.03$, Table S3).

Table 4. Enzymatic stoichiometry displayed as enzymatic (BG + POX): (LAP + NAG), (BG + POX): AP, and (LAP + NAG): $\mathrm{AP}$ activity ratios in topsoil $(0-20 \mathrm{~cm}$ in depth) under different cropping systems in arid and semiarid regions.

\begin{tabular}{ccccc}
\hline Crop & Region & (BG + POX): (LAP + & (BG + POX): AP & (LAP + NAG): AP \\
\hline \multirow{2}{*}{ Maize } & Arid & $1.99 \mathrm{Ba} \pm 0.11$ & $0.94 \mathrm{Aa} \pm 0.11$ & $0.43 \mathrm{Aa} \pm 0.03$ \\
& Semiarid & $2.69 \mathrm{Aa} \pm 0.14$ & $1.11 \mathrm{Aa} \pm 0.12$ & $0.49 \mathrm{Aa} \pm 0.07$ \\
\hline \multirow{2}{*}{ Common bean } & Arid & $1.93 \mathrm{Aa} \pm 0.16$ & $1.18 \mathrm{Aa} \pm 0.12$ & $0.63 \mathrm{Aa} \pm 0.05$ \\
& Semiarid & $1.66 \mathrm{Aa} \pm 0.17$ & $1.12 \mathrm{Aa} \pm 0.14$ & $0.83 \mathrm{Aa} \pm 0.10$ \\
\hline
\end{tabular}

Note. Values are means \pm 1 SE ( $n=5$ for maize and $n=4$ for common bean crops). Abbreviations: AP, acid phosphatase; BG, $B-1,4-$ glucosidase; LAP, leucine aminopeptidase; NAG, B-1,4-N-acetylglucosaminidase; POX, polyphenol oxidase. Different capital letters indicate means are significantly different $(p<0.05)$ when testing for differences between regions within a crop. Different lowercase letters indicate means are significantly different $(p<0.05)$ when testing for differences between crops within a region.

The enzymatic vectors (length and angle) for soils under maize and common bean crops are shown in Figure 1. Generally, the soil from both regions showed enzymatic vector angles above $45^{\circ}$, suggesting a general $\mathrm{P}$ limitation for microorganism growth. Paired comparisons of angles using the Tukey-Kramer HSD test indicated that inter-region variation was statistically indistinguishable $(p>0.05)$. In addition, the paired comparisons of lengths, also using the Tukey-Kramer HSD test, showed that the soils of the common bean plots have smaller vector lengths than the soils of their maize counterpart $(p<0.05)$, possibly indicating higher levels of $C$ limitation for the activity of soil microorganisms, regardless of region $(p<0.01)$. 


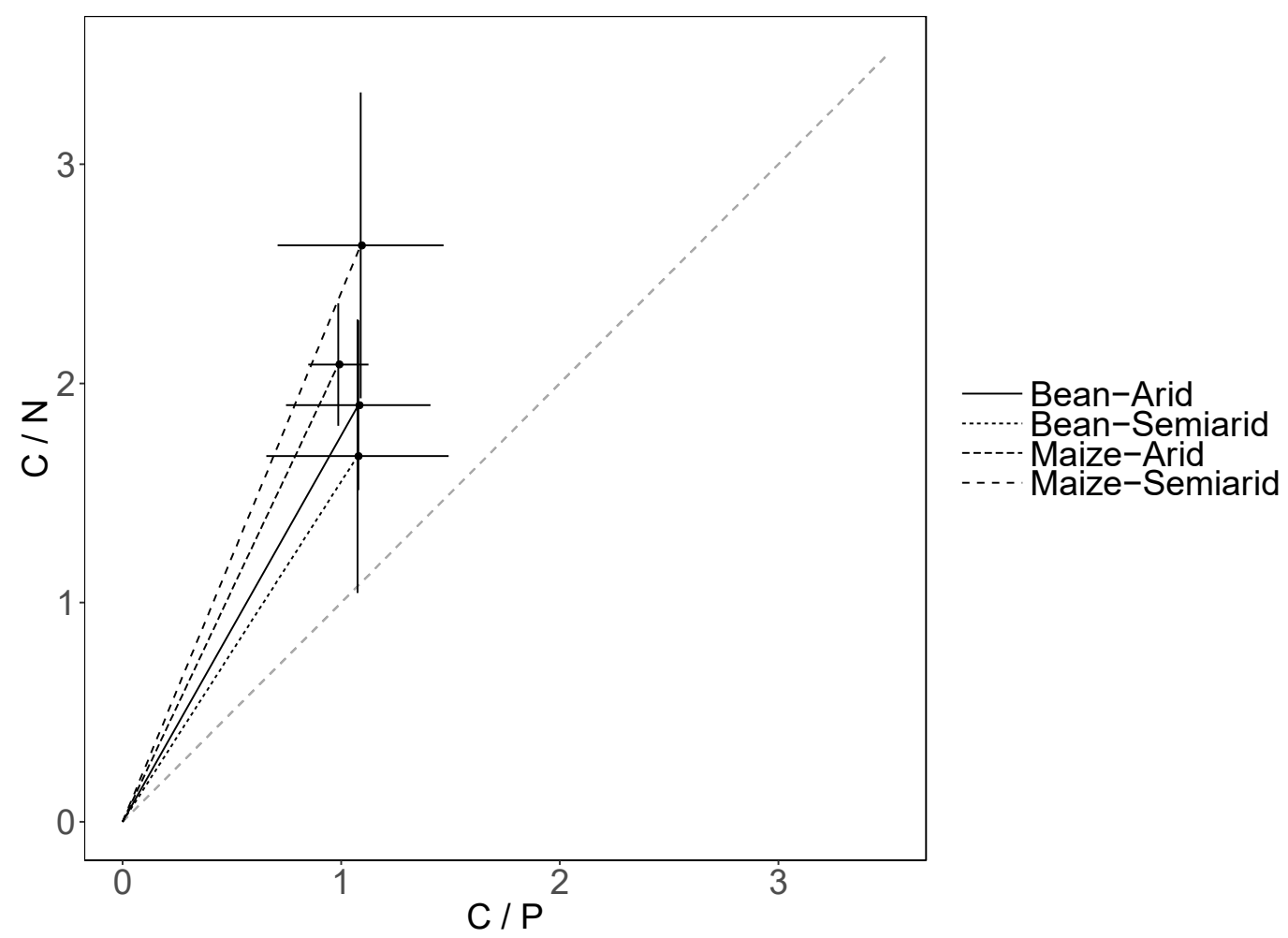

Figure 1. Vectors of enzymatic stoichiometry carbon: nitrogen and carbon: phosphorus activity ratios in soils under maize and common bean cropping in arid and semiarid regions.

\subsection{Soil Microbial Community Composition and Diversity}

Decreasing precipitation had a significant impact on soil bacterial phylogenetic diversity. It was found that the number of bacterial and fungal OTUs was higher in the arid region ( $351 \pm 5.4$ and $822 \pm 8.7$, respectively; mean $\pm 1 \mathrm{SE}$ ) than in the semiarid one (272 \pm 4.0 and $764 \pm 7.0$, respectively) $(p<0.01)$. The fungi-to-bacteria abundance ratio varied from 2.2 to 3.5 and decreased with a decrease in precipitation amount $(p<0.05)$. The Shannon and Simpson indices indicated that soil bacterial diversity increased with decrease precipitation amount (Table 5; $p<0.001$ and $p=0.002$, respectively, Table S4). Additionally, there was a reduction in bacterial diversity under maize crop relative to its diversity under common bean crop ( $p=0.01$ in the case of Shannon index, and $p=0.02$ in the case of the Simpson index). In contrast, there were no significant differences in fungi diversity whether comparing regions or crops (Table $5 ; p=0.28$ to 0.94 , Table S4).

Table 5. Shannon and Simpson diversity indices for bacteria and fungi communities in topsoil (0-20 cm in depth) under different cropping systems in arid and semiarid regions.

\begin{tabular}{cccccc}
\hline Crop & Region & \multicolumn{2}{c}{ Shannon Index $(\boldsymbol{H})$} & \multicolumn{2}{c}{ Simpson Index $(\boldsymbol{D})$} \\
\hline \multirow{2}{*}{ Maize } & & Bacteria & Fungi & Bacteria & Fungi \\
& Arid & $5.44 \mathrm{Aa} \pm 0.04$ & $4.19 \mathrm{Aa} \pm 0.12$ & $0.991 \mathrm{Aa} \pm 0.0005$ & $0.936 \mathrm{Aa} \pm 0.0098$ \\
& Semiarid & $4.97 \mathrm{Bb} \pm 0.04$ & $4.11 \mathrm{Aa} \pm 0.12$ & $0.987 \mathrm{Bb} \pm 0.0006$ & $0.948 \mathrm{Aa} \pm 0.0089$ \\
\hline \multirow{2}{*}{ Common bean } & Arid & $5.51 \mathrm{Aa} \pm 0.05$ & $4.31 \mathrm{Aa} \pm 0.13$ & $0.992 \mathrm{Aa} \pm 0.0005$ & $0.941 \mathrm{Aa} \pm 0.0106$ \\
& Semiarid & $5.27 \mathrm{Ba} \pm 0.05$ & $3.84 \mathrm{Aa} \pm 0.13$ & $0.990 \mathrm{Aa} \pm 0.0006$ & $0.923 \mathrm{Aa} \pm 0.0111$ \\
\hline
\end{tabular}

Note. Values are means $\pm 1 \mathrm{SE}$ ( $n=5$ for maize and $n=4$ for common bean crops). Different capital letters indicate means are significantly different $(p<0.05)$ when testing for differences between regions within a crop. Different lowercase letters indicate means are significantly different $(p<0.05)$ when testing for differences between crops within a region. 
Dominant groups in the bacterial community were very consistent across regions within each of the crops. The most abundant groups were Proteobacteria, Actinobacteria, and Acidobacteria in all soils, with an average of $76 \%$ of the total bacterial sequences (Figure $2 a$ ). On the other hand, Ascomycota phylum dominated the fungal community (accounted for $69 \%$ of the total fungal sequences), followed by Basidiomycota (6\%); approximately $23 \%$ of the fungal OTUs could not be classified (Figure $2 b$ ). Although Proteobacteria and Actinobacteria consistently were the most abundant species, their abundances were sensitive to precipitation regimen increasing with decrease in precipitation amount $(p<0.001$, Table S5). Acidobacteria abundance across regions varied as a function of crop (crop*region effect, $p<0.001)$. In contrast, there was no regional pattern in abundances of the dominant fungal group Ascomycota ( $p=0.97$, Table S6). Regional patterns in Basidiomycota abundances varied as a function of crop system (crop*region effect, $p<0.001$ ). The effect of region on Basidiomycota abundances was much stronger under maize crops (its abundance increased by a factor of 2 with a decrease in rainfall amount), than it was under the common bean crops (abundances increased by $17 \%$ with an increase in rainfall amount).

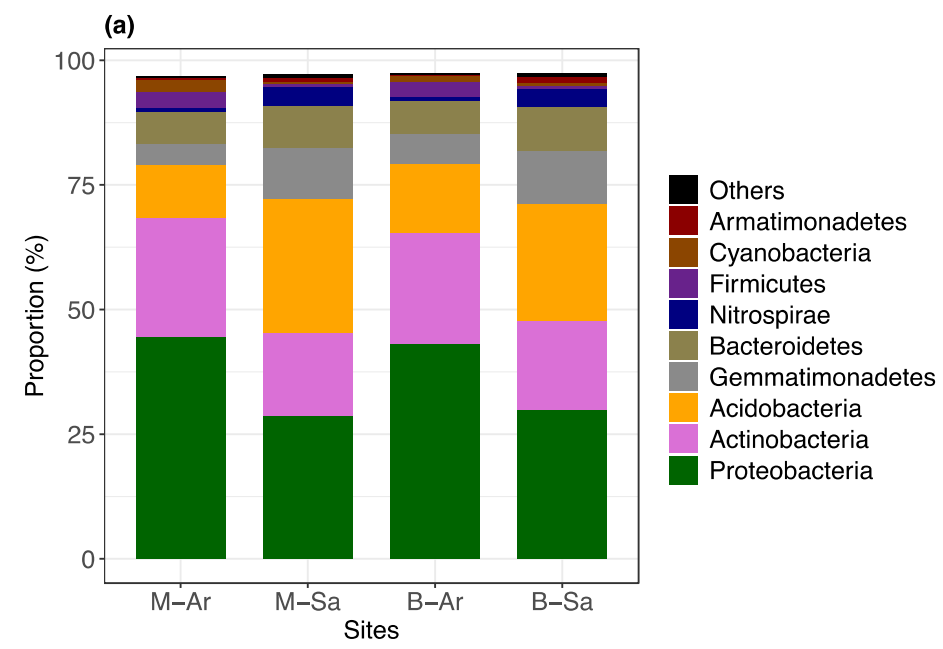

(b)

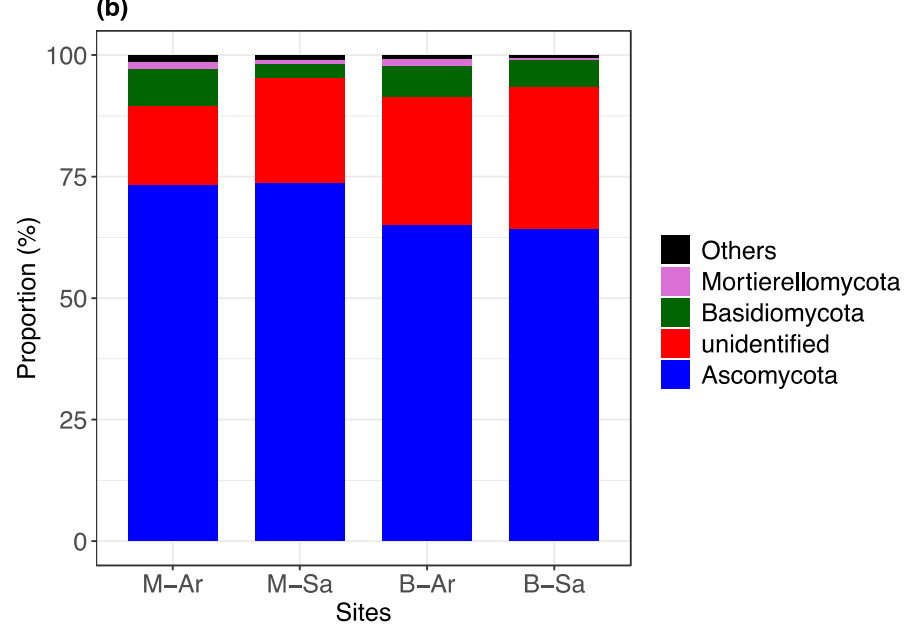

Figure 2. Bacterial (a) and fungal (b) community compositions at the phylum level in soils under maize $(M)$ and common bean $(B)$ cropping in arid $(A r)$ and semiarid $(S a)$ regions.

The pattern of abundances across regions detected in the dominant groups of soil bacteria and fungi was not consistent in the less common phyla. In these less common phyla, only Firmicutes (range of variation in the relative abundance of 1-4\%) showed significant variation with a comparable response to that exhibited by dominant groups (i.e., they were more abundant in soils from the arid region; $p<0.001$, Table S5). In contrast, the relative abundance of Bacteroidetes (6-9\%) and Nitrospirae (4-10\%) increased with an increase in 
precipitation amount $(p<0.001$, in both cases). Abundances of Gemmatimonadetes (4-10\%), Cyanobacteria (0.6-1.8\%), and Armatimonadetes (0.2-1.2\%), as well as of Mortierellomycota $(0.4-2 \%)$ across regions varied as a function of crop (region*crop effect, $p=0.01$ to 0.002 , Tables S5 and S6).

\subsection{Multivariate Analysis and Soil Metric Relationships}

The first two principal component (PC) axes together explained 58\% of the variance of soil data and showed a clear distinction between regions in terms of soil biogeochemical and microbial community composition (Figure 3). Specifically, the plots of the semiarid region showed greater dispersion within biplots (by a factor of 6) compared to those of the arid region $(p<0.001)$, indicating a decrease in soil heterogeneity with a decrease in precipitation. The first PC axis (PC1) clearly separated the study plots considering the precipitation regimen. Soil organic C, total $\mathrm{P}$, and total N, and Acidobacteria, Nitrospirae, Gemmatimonadetes, Bacteroidetes, and Armatimonadetes, loaded strongly in the same direction on PC1, which explained $40 \%$ of the variation among soil metrics (Figure 3, Table 6). In contrast to this direction, Proteobacteria, Actinobacteria, Firmicutes, and Cyanobacteria were loaded on the same first PC axis and related to arid plots, indicating that bacterial groups were more sensitive than fungi to water stress. The second PC axis (PC2) explained 18\% of the variance and represented a soil enzyme-activity axis, which was positively correlated with P (acid phosphatase), N (ß-1,4-N-acetylglucosaminidase), and C (polyphenol oxidase and 1 -1,4-glucosidase) enzymes, but negatively correlated with leucine aminopeptidase. In addition to the decrease in biogeochemical and microbial heterogeneity observed with the increase of drought, the number of significant correlations between soil metrics decreased by $\sim 50 \%$ with the decrease in precipitation amount (from 33 in the semiarid site to 16 in the arid counterpart) (Table S7).

Table 6. Eigenvalues, cumulative percent variation, and eigenvectors of the first three principal components (PCs) for the topsoil (0-20 cm in depth) characteristics that best predicted the soil biogeochemical and soil microbial composition spectrums.

\begin{tabular}{|c|c|c|c|}
\hline & PC1 & PC2 & PC3 \\
\hline Eigenvalue & 7.929 & 3.625 & 2.546 \\
\hline Cumulative percent variation & 39.65 & 57.77 & 70.5 \\
\hline \multicolumn{4}{|l|}{ Eigenvectors } \\
\hline Soil organic carbon (OC) & $-0.96^{* * *}$ & 0.17 & -0.02 \\
\hline Soil total nitrogen (TN) & $-0.64^{* *}$ & 0.16 & -0.12 \\
\hline Soil total phosphorus (TP) & $-0.75^{* * *}$ & 0.42 & 0.15 \\
\hline ß-1,4-glucosidase (Bg) & -0.19 & $0.80^{* * *}$ & 0.15 \\
\hline Polyphenol oxidase (Pox) & 0.05 & $0.73^{* * *}$ & 0.21 \\
\hline Leucine aminopeptidase (Lap) & 0.40 & $-0.77^{* * *}$ & -0.19 \\
\hline B-1,4-N-acetylglucosaminidase (Nag) & 0.28 & $0.72 * * *$ & -0.05 \\
\hline Acid phosphatase (Ap) & 0.03 & $0.89^{* * *}$ & 0.03 \\
\hline Acidobacteria (1) & $-0.95^{* * *}$ & -0.11 & 0.02 \\
\hline Actinobacteria (2) & $0.82^{* * *}$ & 0.01 & 0.34 \\
\hline Armatimonadetes (3) & $-0.58 *$ & -0.20 & 0.47 \\
\hline Ascomycota (4) & 0.09 & -0.06 & $-0.60^{* *}$ \\
\hline Bacteroidetes (5) & $-0.58 *$ & -0.08 & -0.36 \\
\hline Basidiomycota (6) & 0.56 * & -0.25 & $0.55 *$ \\
\hline Cyanobacteria (7) & $0.62 * *$ & -0.04 & $0.48 *$ \\
\hline Firmicutes (8) & $0.62 * *$ & 0.14 & $-0.64 * *$ \\
\hline Gemmatimonadetes (9) & $-0.80^{* * *}$ & -0.08 & -0.16 \\
\hline Mortierellomycota (10) & 0.44 & 0.23 & $-079^{* * *}$ \\
\hline Nitrospirae (11) & $-0.90^{* * *}$ & -0.31 & -0.01 \\
\hline Proteobacteria (12) & $0.89^{* * *}$ & 0.16 & -0.02 \\
\hline
\end{tabular}




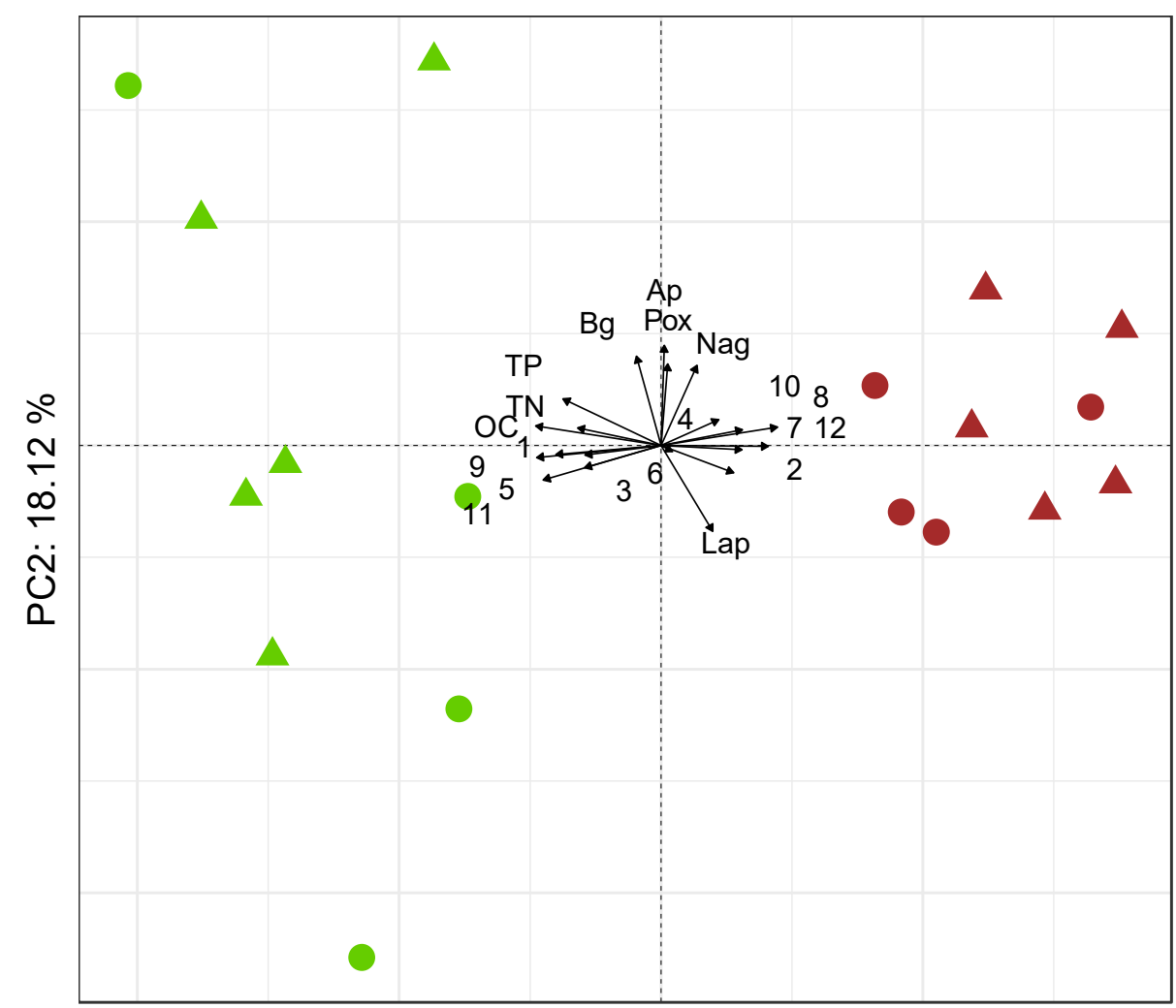

PC1: $39.65 \%$

\section{Crop $\triangle$ Maize $\bullet$ Bean Climate $\bullet$ Arid $\bullet$ Semiarid}

Figure 3. Principal components (PC) analyses biplots of the soil data under maize and common bean cropping in arid and semiarid regions. OC, organic carbon; $\mathrm{TN}$, total nitrogen; TP, total phosphorus Ap, acid phosphatase; Bg, B-1,4-glucosidase; Lap, leucine aminopeptidase; Nag, B-1,4-Nacetylglucosaminidase; Pox, polyphenol oxidase; 1, Acidobacteria; 2, Actinobacteria; 3 , Armatimonadetes; 4, Ascomycota; 5, Bacteroidetes; 6, Basidiomycota; 7, Cyanobacteria; 8, Firmicutes; 9, Gemmatimonadetes; 10, Mortierellomycota; 11, Nitrospirae; 12, Proteobacteria.

\section{Discussion}

It is expected that many tropical semiarid regions will suffer droughts with increasing frequency and intensity over this century [14]; since this change in climate will likely alter the functions of tropical agricultural ecosystems and the yield of major crops [54], we sought to contribute to the understanding of how soil biogeochemistry and microbial diversity in rainfed agriculture may be sensitive to differences in precipitation regimes.

\subsection{Differences in Soil-Plant Relationships with Changes in Precipitation Regime}

Climate impacts on food security will involve negative impacts on crop yields. However, unlike other studies [55-57], we were not able to detect a substantial change in yield variability (for both common bean and maize) across regions despite the variation in precipitation regimes (Table 1). Nevertheless, aridity had different impacts on nutrient cycling. For example, low precipitation amounts can drive a decrease in soil total $\mathrm{N}$ without consequences for leaf and fine root $\mathrm{N}$ concentrations in common bean plants. In contrast, although soil total P concentration did not vary with increased aridity in bean agroecosystems, its concentration in leaves and roots did increase with increased aridity. Thus, this evidence suggests that, under arid conditions, this legume would have greater $\mathrm{P}$ concentrations in leaves to compensate for the expected lower photosynthetic rates induced by reduced stomatal conductance [58]. This would also happen in roots, enhancing root 
metabolism and growth for the uptake of soil nutrients and water [59]. Moreover, it was observed that beans in the arid region allocated more resources to roots (root biomass increases by a factor of 2 with a decrease MAP; Table 1). Thus, the data indicated differences in resource investment strategies for common bean plants under increased aridity, as would be expected under an 'optimal partitioning theory' [60]. On the other hand, in maize, the observed decrease in soil total $\mathrm{N}$ with increased aridity had consequences for leaf and fine root $\mathrm{N}$ concentrations. However, in maize, $\mathrm{P}$ concentrations in leaves and roots and root biomass were insensitive to more extended and frequent precipitation shortages, probably reflecting better adaptation to aridity in this $\mathrm{C}_{4}$ species.

These results show a striking contrast in the consequences of increased aridity in rainfed agriculture between biological $\mathrm{N}$-fixation species and species without this capacity. Overall, our results support the conclusion that increased aridity results in $\mathrm{N}$ depletion in maize, and more efficient $P$ cycling in beans. The scarcer and more seasonal precipitation in the arid region, as compared to its semiarid counterpart, possibly leads to a mismatch between the time when most of the $\mathrm{N}$ is mineralized by soil microbes and the time of greatest $\mathrm{N}$ uptake by plants [61], something that needs to be taken into account in management practices of rainfed agriculture in drylands worldwide under climate change.

\subsection{Nutrient Limitation in Agricultural Ecosystems in Tropical Arid Lands}

Despite P fertilization, P limitation may occur in the studied soils, and the deficit in soil P may lead to a loss of attainable yield of both crops (see the low yield in maize and bean crops in both regions in Table 1). Our results indicate that agricultural soils in both regions had elevated phosphatase activity (a sensitive indicator of limited P supply for ecosystem demand; [62]). This nutrient limitation was also revealed by enzymatic vector angles above $45^{\circ}$ in agricultural soils, which are often related to an increase in microbial investment in $\mathrm{P}$ acquisition under low $\mathrm{P}$ supply $[42,63]$. These results are consistent with other studies showing that soil microorganisms are P-limited in native $[23,64,65]$ and agricultural ecosystems $[17,25]$. Furthermore, we saw no differences in vector angles across regions (following the proposal to use indicator enzymes to reflect P-acquiring effort; [29]), as could be expected due to the limited mobility and dissolution of P in dry tropical soils. This condition would be exaggerated in our drier sites. We cannot determine whether such lack of expected responses to increased aridity resulted from chemical P fertilization (i.e., an indirect consequence of an increase in P supply) or whether it reflects highly efficient use of this extra anthropogenic P input by crops (as suggested by the observed increase in $\mathrm{P}$ concentrations in leaves and roots of common bean plants in the arid region), or both. In contrast, the $\mathrm{N}$ cycle seems to be sustained by the chemical fertilization, and to large extent by atmospheric and biological processes, the latter of which may be augmented by abundant microbial $\mathrm{N}$ fixation in tropical soils $[66,67]$.

In contrast to other studies that indicate that microorganisms in tropical soils are primarily limited by $\mathrm{C}$ and secondarily limited by $\mathrm{P}[23,68]$, our data suggest that $\mathrm{P}$ limitation is generalized in these arid and semiarid soils, affecting the relative microbial investments in P-acquiring enzymes that may be related to common (e.g., Actinobacteria) and rare (e.g., Firmicutes) bacterial abundances, water-stress tolerant organisms with the capacity to release unavailable P [69-71]. On the other hand, our analyses suggest that C limitation is common for bean systems in both regions, despite that generally the precipitation stimulates the mineralization of soil organic $C$ [72]. The $C$ limitation for soil microbial function in the common bean soils could be related to bacterial demand, due to the fact that fungi often exhibit a more flexible C:N:P stoichiometry and are better at using crop litter resources than bacteria $[73,74]$.

\subsection{Soil Biogeochemistry and Microbial Community Composition Are Sensitive to Drought Increase}

We found that the precipitation regime was linked to clear differences in soil biogeochemistry and microbial community composition, as indicated by our multivariate analysis. In particular, the lower dispersion of arid plots showed in the PCA indicate that increased 
aridity reduces soil biogeochemical heterogeneity [75], while higher intra-annual variability in precipitation leads to lower coordination in the soil functioning as was evidenced by the Pearson correlation analysis, which could affect the food security [5].

Predicted increases in aridity are expected to lead to severe nutrient depletion, particularly in the most arid sites [76]. Our results show that despite inorganic fertilization decreased the concentration of $\mathrm{N}$ (and also of $\mathrm{C}$ ), it did not increase the concentration of $\mathrm{P}$ (as expected by the low P mobility in the soil), hence affecting soil C, N, and P balance in the arid region. Thus, we observed an abrupt decrease in the C:P and N:P ratios from semiarid to arid regions. These abrupt changes indicate that biologically controlled $\mathrm{C}$ and $\mathrm{N}$ cycles seem to become uncoupled from $\mathrm{P}$ biogeochemically controlled cycles in response to increasing aridity, with negative consequences for the reduced crop yields.

In turn, the soil microbial community composition was less variable within the arid region than within its semiarid counterpart, as indicated by a decrease in bacterial $a$ diversity with increased aridity. The observed uncoupling of $a$ - and $ß$-diversity suggests the homogenization of soil microbial community composition and a net loss of its biodiversity in the soil with increased aridity as was observed in other studies $[77,78]$. This lower microbial taxonomic diversity suggests a lower soil functional capacity $[79,80]$ with aridity.

Our results, particularly the increase in the fungi to bacterial abundance ratio with aridity, are consistent with previous reports showing that fungi are more resistant to drought than bacteria $[81,82]$. Although the precipitation regime has a legacy effect on the composition of the fungal community [83], fungi can be more tolerant to extreme drought than bacteria. Furthermore, fungi diversity displayed no regional trends. Our study also indicated that bacterial community composition remained stable under drier conditions, possibly due to attenuation of bacteria as a result of extended drought exposure [84] and/or altered functionality to build up resilience [85]. Despite this resilience in community composition, variance in the responses of more abundant gram-positive bacteria was observed and could be explained in terms of distinct classes within this group [86]. For example, the abundance of gram-negative bacteria, such as Proteobacteria, increased with aridity. Meanwhile, the abundance of other gram-negative bacteria, such as Acidobacteria, decreased in the function of the crop system, thus reflecting that these taxa are not universally linked to aridity and showing varying trends in response to changes in water stress $[87,88]$. The differences between both groups in response to drought increase could be related to changes in soil organic $C$ composition and bacterial $C$ metabolizing patterns [80], since Proteobacteria abundance increases with higher $\mathrm{C}$ mineralization rates, and Acidobacteria abundance increases with lower $C$ mineralization rates, which is driven by the stronger water pulses effects on soil organic matter decomposition with aridity [89]. Additionally, a higher abundance of gram-positive bacteria, such as Actinobacteria, found in the arid region, may indicate that the bacterial community composition in these agricultural ecosystems shifts due to osmotic stress. Gram-positive bacteria are known to be more drought tolerant (stronger cell wall and drought avoidance strategies such as spore formation) than gramnegative bacteria $[90,91]$. Thus, we speculate that these microbial taxonomic shifts were likely due to osmotic stress caused by the lower precipitation amount in the arid region. This is consistent with other evidence $[83,92,93]$ that found similar relationships between drought and soil bacterial community responses, reflecting the opportunistic strategy of typical copiotrophs with high growth rates (e.g., Proteobacteria; [94]).

We also observed a decrease in the abundance of rare bacterial taxa with an increase in aridity. Rare soil microorganisms can be highly active and diverse [95], contributing to processes in the soil even with low abundance [96]. Moreover, the growth rates of rare microbes are not necessarily different from abundant ones [97]. As such, drought intensification may potentially lead to altered composition of the microbial community through effects on rare members of the community, with negative consequences for ecosystem stability and functioning [98] in view of the strong links between rare taxa and soil ecosystem processes [95]. 
The analysis of enzyme activity, a proxy of the microbial nutrient demand, indicates similar activity for all enzymes (i.e., C-, N- and P-acquiring enzymes) across regions despite changes in aridity and the observed greater substrate accumulation when xeric condition increase (Table 2). Similar enzyme activity across regions could be due to reduced competition with plants under increasing drought, given that the levels at which microbes become water-limited are typically much lower than those for plants [99], and/or too large organic matter inputs from the death of more abundant root biomass (Table 1). The lack of changes in enzyme activities across regions is also possible due in part to the interplay of two factors whose relative contributions are difficult to quantify: the shift in microbial community composition along these regions and increasing efficiency within microbial species as they respond to reduced nutrient availability or water stress [100].

Aside from the soil microbial diversity and biogeochemical patterns observed, our study on the consequences of the regional variation in precipitation regimen in drylands of Mexico, allows us to identify that the effect of drought intensification on Basidiomycota (a fungal group including mycorrhizal species and pathogens of bean and maize crops $[101,102])$ abundance in these agroecosystems will vary, depending on the details of the identity of crop species. Given the potential for crop system sustainability in response to the massive impact of climate change on rainfed agricultural systems in tropical drylands, the topic of the present study warrants subsequent investigation.

\section{Conclusions}

The future of rainfed agriculture in tropical regions is uncertain; particularly, the regulation of major biogeochemical cycles is expected to be modified by changes in the precipitation regime. Our data suggest that there is a phosphorus limitation for microbial growth in soils across the studied regions. This generalized limitation of microbial activity by phosphorus supply may have profound effects on crop productivity in semiarid and arid regions. Although the intensity of this P-limitation was not sensitive to aridity increase, our findings suggest that the predicted precipitation reduction in arid lands will disrupt carbon, nitrogen, and phosphorus balance in soils, and will alter both the composition of soil microbial communities and the resource investment strategies of maize and common bean plants. In a scenario in which decreases in mean annual precipitation uncouple biogeochemical cycles and homogenizes soil microbial biodiversity, the vulnerability of rainfed agricultural ecosystems would increase with severe consequences for the livelihoods of the people in the drylands of central Mexico.

Supplementary Materials: The following are available online at https://www.mdpi.com/article/ 10.3390/su132111848/s1, Table S1: Analysis of variance (ANOVA) for soil organic carbon, total nitrogen and total phosphorus concentrations considering the main effects (crop and region) and their interaction (crop*region), Table S2: Analysis of variance (ANOVA) for enzyme activities considering the main effects (crop and region) and their interaction (crop*region). Table S3: Analysis of variance (ANOVA) for enzyme stoichiometry activity ratios considering the main effects (crop and region) and their interaction (crop*region). Table S4: Analysis of variance (ANOVA) of soil microbial diversity considering the main effects (crop and region) and their interaction (crop*region). Table S5: Analysis of deviance (ANODEV) of soil bacterial abundance considering the main effects (crop and region) and their interaction (crop*region). Table S6: Analysis of deviance (ANODEV) of soil fungi abundance considering the main effects (crop and region) and their interaction (crop*region).

Author Contributions: Conceptualization, M.B., J.C., A.E.E., J.A.R. and A.W.; investigation, T.F.A., M.A., K.C.-E., V.P., A.B.-S., U.I.S.C., R.C.-O., J.C., A.E.E. and J.A.R.; data analysis, T.F.A., M.A. and K.C.-E.; original draft preparation, T.F.A., M.A., K.C.-E., A.E.E., J.A.R. and J.C.; writing-review \& editing, J.C.; project administration, M.B.; funding acquisition, M.B. and A.E.E. All authors have read and agreed to the published version of the manuscript.

Funding: This research was funded by Mexico's National Council of Science and Technology (CONACYT) grant number 247672.

Institutional Review Board Statement: Not applicable. 
Informed Consent Statement: Not applicable.

Data Availability Statement: Data are available upon request to the corresponding author.

Acknowledgments: We dedicate this work to Ulises Isaac Salazar Cabrera, a great postgraduate student that contributed to advance in our understanding of soils of these dryland regions. The authors would like to thank to Mexico's National Council of Science and Technology (CONACYT) grant (247672) for financial support of this work. The authors also would like to thank Denisse Arroyo, Enrique Solís and A. Uscanga for the contribution in the laboratory analyses. Finally, with gratitude to the landowners and managers who facilitated the field work.

Conflicts of Interest: The authors declare no conflict of interest.

\section{References}

1. Mendoza-Ponce, A.; Corona-Núñez, R.; Kraxner, F.; Leduc, S.; Patrizio, P. Identifying effects of land use cover changes and climate change on terrestrial ecosystems and carbon stocks in Mexico. Glob. Environ. Chang. 2018, 52, 12-23. [CrossRef]

2. Hannah, L.; Ikegami, M.; Hole, D.G.; Seo, C.; Buchart, S.H.M.; Peterson, A.T.; Roehrdanz, P.R. Global climate change adaptation priorities for biodiversity and food security. PLoS ONE 2013, 8, e72590. [CrossRef]

3. Granados, R.; Soria, J.; Cortina, M. Rainfall variability, rainfed agriculture and degree of human marginality in North Guanajuato, Mexico. Singap. J. Trop. Geogr. 2017, 38, 153-166. [CrossRef]

4. Pontifes, P.A.; García-Meneses, P.M.; Gómez-Aíza, L.; Monterroso-Rivas, A.I.; Caso Chavéz, M. Land use/land cover change and extreme climatic events in the arid and semi-arid ecoregions of Mexico. Atmósfera 2018, 31, 355-372. [CrossRef]

5. D'Odorico, P.; Bhattachan, A. Hydrologic variability in dryland regions: Impacts on ecosystem dynamics and food security. Philos. Trans. R. Soc. B 2012, 367, 3145-3157. [CrossRef]

6. Figueroa, D.; Ortega-Fernández, P.; Abbruzzini, T.F.; Rivero-Villar, A.; Galindo, F.; Chávez-Vergara, B.; Etchevers, J.D.; Campo, J. Effects of land use change from native forest to livestock on soil C, N and P dynamics along a rainfall gradient in Mexico. Sustainability 2020, 12, 8656. [CrossRef]

7. Donatti, C.I.; Harvey, C.A.; Martínez-Rodríguez, M.R.; Vignola, R.; Rodriguez, C.M. Vulnerability of smallholder farmers to climate change in Central America and Mexico: Current knowledge and research gaps. Clim. Develop. 2019, 11, $264-286$. [CrossRef]

8. Bradford, J.B.; Schlaepfer, D.R.; Lauenroth, W.K.; Yackulic, C.B.; Duniway, M.; Hall, S.; Jia, G.; Jamiyansharav, K.; Munson, S.M.; Wilson, S.D.; et al. Future soil moisture and temperature extremes imply expanding suitability for rainfed agriculture in temperate drylands. Sci. Rep. 2017, 7, 1-11. [CrossRef] [PubMed]

9. Sidibé, Y.; Foudi, S.; Pascual, U.; Termansen, M. Adaptation to climate change in rainfed agriculture in the Global South: Soil biodiversity as natural insurance. Ecol. Econ. 2018, 146, 588-596. [CrossRef]

10. Wani, S.P.; Rockström, J.; Oweis, T. Rainfed Agriculture: Unlocking the Potential; CAB International: London, UK, 2009.

11. Acosta-Martínez, V.; Cotton, J.; Gardner, T.; Moore-Kucera, J.; Zak, J.; Wester, D.; Cox, S. Predominant bacterial and fungal assemblages in agricultural soils during a record drought/heat wave and linkages to enzyme activities of biogeochemical cycling. Appl. Soil Ecol. 2014, 84, 69-82. [CrossRef]

12. Wang, P.; Marsh, E.L.; Kruger, G.; Lorenz, A.; Schachtman, D.P. Belowground microbial communities respond to water deficit and are shaped by decades of maize hybrid breeding. Environ. Microbiol. 2020, 22, 889-904. [CrossRef]

13. Pugnaire, F.I.; Morillo, J.A.; Peñuelas, J.; Reich, P.B.; Bardegett, R.D.; Gaxiola, A.; Wardle, D.A.; van der Putten, W.H. Climate change effects on plant-soil feedbacks and consequences for biodiversity and functioning of terrestrial ecosystems. Sci. Adv. 2019, 5, eaaz1834. [CrossRef]

14. Chadwick, R.; Good, P.; Martin, G.; Rowell, D.P. Large rainfall changes consistently projected over substantial areas of tropical land. Nat. Clim. Chang. 2016, 6, 177. [CrossRef]

15. Elser, J.J.; Bracken, M.E.S.; Cleland, E.E.; Gruner, D.S.; Harpole, W.S.; Hillebrand, H.; Ngai, J.T.; Seabloom, E.W.; Shurin, J.B.; Smith, J.E. Global analysis of nitrogen and phosphorus limitation of primary producers in freshwater, marine and terrestrial ecosystems. Ecol. Lett. 2007, 10, 1135-1142. [CrossRef] [PubMed]

16. Townsend, A.R.; Cleveland, C.C.; Houlton, B.Z.; Alden, C.B.; White, J.W.C. Multi-element regulation of the tropical forest carbon cycle. Front. Ecol. Environ. 2011, 9, 9-17. [CrossRef]

17. Hou, E.; Luo, Y.; Kuang, Y.; Chen, C.; Lu, X.; Jiang, L.; Luo, X.; Wen, D. Global meta-analysis shows pervasive phosphorus limitation of aboveground plant production in natural terrestrial ecosystems. Nat. Commun. 2020, 11, 637. [CrossRef] [PubMed]

18. Campo, J.; Vázquez-Yanes, C. Effects of nutrient limitation on aboveground carbon dynamics during tropical dry forest regeneration in Yucatán, Mexico. Ecosystems 2004, 7, 311-319. [CrossRef]

19. Condit, R.; Engelbrecht, B.M.J.; Pino, D.; Pérez, R.; Turner, B.L. Species distributions in response to individual soil nutrients and seasonal drought across a community of tropical trees. Proc. Natl. Acad. Sci. USA 2013, 110, 5064-5068. [CrossRef]

20. Weil, R.R.; Brady, N.C. The Nature and Properties of Soils, 15th ed.; Pearson: Columbus, OH, USA, 2017.

21. MacDonald, G.K.; Bennett, E.M.; Potter, P.A.; Ramankutty, N. Agronomic phosphorus imbalances across the world's croplands. Proc. Natl. Acad. Sci. USA 2011, 108, 3086-3091. [CrossRef] 
22. Bardgett, R.D.; van der Putten, W.H. Belowground biodiversity and ecosystem functioning. Nature 2014, 515, 505-511. [CrossRef]

23. Cleveland, C.C.; Townsend, A.R.; Schmidt, S.K. Phosphorus limitation of microbial processes in moist tropical forests: Evidence from short-term laboratory incubations and field studies. Ecosystems 2002, 5, 680-691. [CrossRef]

24. Turner, B.L.; Wright, S.J. The response of microbial biomass and hydrolytic enzymes to a decade of nitrogen, phosphorus, and potassium addition in a lowland tropical rain forest. Biogeochemistry 2014, 117, 115-130. [CrossRef]

25. Ringeval, B.; Augusto, L.; Monod, H.; van Apeldoorn, D.; Bouwman, L.; Yang, X.; Achat, D.L.; Chini, L.P.; Van Oost, K.; Guenet, B.; et al. Phosphorus in agricultural soils: Drivers of its distribution at the global scale. Glob. Chang. Biol. 2017, 23, 3418-3432. [CrossRef]

26. Margalef, O.; Sardans, J.; Fernández-Martínez, M.; Molowny-Horas, R.; Janssens, I.A.; Ciais, P.; Goll, D.; Richter, A.; Obersteiner, M.; Asensio, D.; et al. Global patterns of phosphatase activity in natural soils. Sci. Rep. 2017, 7, 1337. [CrossRef]

27. Sterner, R.W.; Elser, J.J. Ecological Stoichiometry: The Biology of Elements from Molecules to the Biosphere; Princeton University Press: Princeton, NJ, USA, 2002.

28. Demoling, F.; Figueroa, D.; Bååth, E. Comparison of factors limiting bacterial growth in different soils. Soil Biol. Biochem. 2007, 39, 2485-2495. [CrossRef]

29. Sinsabaugh, R.L.; Hill, B.H.; Follstad Shah, J.J. Ecoenzymatic stoichiometry of microbial organic nutrient acquisition in soil and sediment. Nature 2009, 468, 795-798. [CrossRef] [PubMed]

30. Cleveland, C.C.; Liptzin, D. C:N:P stoichiometry in soil: Is there a "Redfield ratio" for the microbial biomass? Biogeochemistry 2007, 85, 235-252. [CrossRef]

31. Schimel, J.P.; Weintraub, M.N. The implications of exoenzyme activity on microbial carbon and nitrogen limitation in soil: A theoretical model. Soil Biol. Biochem. 2003, 35, 549-563. [CrossRef]

32. FAO. The State of Food Security and Nutrition in the World; Food and Agriculture Organization of the United Nations: Rome, Italy, 2019.

33. Conde, C.; Estrada, F.; Martínez, B.; Sánchez, O.; Gay, C. Regional climate change scenarios for Mexico. Atmósfera 2011, 24, $125-140$.

34. Middleton, N.; Thomas, S.G. World Atlas of Desertification, 2nd ed.; Arnold: London, UK, 1997.

35. Mexico's National Meteorological Service. Long-Term Climatological Data. Available online: https://smn.conagua.gob.mx/es/ informacion-climatologica-por-estado?estado=mex (accessed on 7 May 2021).

36. SAGARPA. Planeación Agrícola Nacional 2017-2030: Maíz Mexicano; Secretaría de Agricultura, Ganadería, Desarrollo Rural, Pesca y Alimentación: Mexico City, Mexico, 2017.

37. SAGARPA. Planeación Agrícola Nacional 2017-2030: Frijol Mexicano; Secretaría de Agricultura, Ganadería, Desarrollo Rural, Pesca y Alimentación: Mexico City, Mexico, 2017.

38. Lynch, J.P.; Brown, K.M. Topsoil foraging: An architectural adaptation of plant to low phosphorus availability. Plant Soil 2001, 237, 225-237. [CrossRef]

39. Jackson, R.B.; Cannadell, J.; Ehleringer, J.R.; Mooney, H.A.; Sala, O.E.; Schulze, E.D. A global analysis of root distributions for terrestrial biomes. Oecologia 1996, 308, 389-411. [CrossRef] [PubMed]

40. Li, H.; Mollier, A.; Ziadi, N.; Shi, Y.; Parent, L.-E.; Morel, C. Soybean root traits after 24 years of different soil tillage and mineral phosphorus fertilization. Soil Till. Res. 2017, 165, 258-267. [CrossRef]

41. Jackson, C.R.; Tyler, H.L.; Millar, J.J. Determination of microbial extracellular enzyme activity in waters, soils, and sediment using High Throughput Microplate Assays. J. Vis. Exp. 2013, 80, e50399. [CrossRef] [PubMed]

42. Moorhead, D.L.; Sinsabaugh, R.L.; Hill, B.H.; Weintraub, M.N. Vector analysis of ecoenzyme activities reveal constraints on coupled C., N and P dynamics. Soil Biol. Biochem. 2016, 93, 1-7. [CrossRef]

43. Marchesi, J.R.; Sato, T.; Weightman, A.J.; Martin, T.A.; Fry, J.C.; Hiom, S.J.; Wade, W.G. Design and evaluation of useful bacterium-specific PCR primers that amplify genes coding for bacterial 16S rRNA. Appl. Environ. Microbiol. 1998, 64, 765-799. [CrossRef]

44. Gardes, M.; Bruns, T.D. ITS primers with enhanced specificity for basidiomycetes application to the identification of mycorrhizae and rusts. Mol. Ecol. 1993, 2, 113-118. [CrossRef]

45. Kazeeroni, E.A.; Al-Sadi, A.M. 454-pyrosequencing reveals variable fungal diversity across farming systems. Front. Plant Sci. 2016, 7, 314. [CrossRef]

46. Caporaso, J.G.; Kuczynski, J.; Stombaugh, J.; Bittinger, K.; Bushman, F.D.; Costello, E.K.; Fierer, N.; Gonzalez Peña, A.; Goodrich, J.K.; Gordon, J.I.; et al. QIIME allows analysis of high-throughput community sequencing data. Nat. Methods 2010, 7, 335-336. [CrossRef]

47. Rebollar, E.A.; Sandoval-Castellanos, E.; Roessler, K.; Gaut, B.S.; Alcaraz, L.D.; Benítez, M.; Escalante, A.E. Seasonal changes in a maize-based polyculture of Central Mexico reshape the co-occurrence networks of soil bacterial communities. Front. Microbiol. 2017, 8, 2478. [CrossRef]

48. Rognes, T.; Flouri, T.; Nichols, B.; Quince, C.; Mahé, F. VSEARCH: A versatile open source tool for metagenomics. Peer J. 2016, 4 , e2584. [CrossRef]

49. DeSantis, T.Z.; Hugenholtz, P.; Larsen, N.; Rojas, M.; Brodie, E.L.; Keller, K.; Huber, T.; Dalevi, D.; Hu, P.; Andersen, G.L. Green genes, a chimera-checked 16S rRNA gene database and workbench compatible with ARB. Appl. Environ. Microbiol. 2006, 72, 5069-5072. [CrossRef] [PubMed] 
50. McMurdie, P.L.; Holmes, S. phyloseq: An R package for reproducible interactive analysis and graphics of microbiome census data. PLOS ONE 2013, 8, e61217. [CrossRef]

51. McCullagh, P. , Nelder, J.A. Generalized Linear Models, 2nd ed.; Chapman and Hall: London, UK, 1989.

52. R Core Team. R: A Language and Environment for Statistical Computing; R Foundation for Statistical Computing: Vienna, Austria, 2019; Available online: https:/ / cran.rproject.org/doc/manuals/release/fullrefman.pdf (accessed on 23 June 2021).

53. Lenth, R. Emmeans: Estimated Marginal Means, Aka Least-Squares Means. R package Version 1.3.3. 2019. Available online: https: / CRAN.R-project.org/package=emmeans (accessed on 23 June 2021).

54. Lesk, C.; Rowhani, P.; Ramankutty, N. Influence of extreme weather disasters on global crop production. Nature 2016, 529, 84-87. [CrossRef] [PubMed]

55. Harrison, M.T.; Tardieu, F.; Dong, Z.; Messina, C.D.; Hammer, G.L. Characterizing drought stress and trait influence on maize yield under current and future conditions. Glob. Chang. Biol. 2014, 20, 867-878. [CrossRef] [PubMed]

56. Iizumi, T.; Ramankutty, N. Changes in yield variability of major crops for 1981-2010 explained by climate change. Environ. Res. Lett. 2016, 11, 034003. [CrossRef]

57. Smith, M.R.; Veneklas, E.; Polania, J.; Rao, I.M.; Beebe, S.E.; Merchant, A. Field drought conditions impact yield but not nutritional quality of the seed in common bean (Phaseolus vulgaris L.). PLoS ONE 2019, 14, e0217099. [CrossRef]

58. Wright, I.J.; Reich, P.B.; Westoby, M. Least-cost input mixtures of water and nitrogen for photosynthesis. Am. Nat. 2003, 161, 98-111. [CrossRef]

59. Sardans, J.; Grau, O.; Chen, H.Y.H.; Janssens, I.A.; Ciais, P.; Piao, S.; Peñuelas, J. Changes in nutrient concentrations of leaves and roots in response to global change factors. Glob. Chang. Biol. 2017, 23, 3849-3856. [CrossRef]

60. Gedroc, J.J.; McConnaughay, K.D.M.; Coleman, J.S. Plasticity in root/shoot partitioning: Optimal, ontogenetic, or both? Funct. Ecol. 1996, 10, 44-50. [CrossRef]

61. Saynes, V.; Hidalgo, C.; Etchevers, J.D.; Campo, J. Soil C and N dynamics in primary and secondary seasonally dry tropical forests in Mexico. Appl. Soil Ecol. 2005, 29, 282-289. [CrossRef]

62. Sullivan, B.W.; Alvarez-Clare, S.; Castle, S.C.; Porder, S.; Reed, S.C.; Schreeg, L.; Townsend, A.R.; Cleveland, C.C. Assessing nutrient limitation in complex forested ecosystems: Alternatives to large-scale fertilization experiments. Ecology 2014, 95, 668-681. [CrossRef]

63. Marklein, A.R.; Houlton, B.Z. Nitrogen inputs accelerate phosphorus cycling rates across a wide variety of terrestrial ecosystems. New Phytol. 2011, 193, 696-704. [CrossRef]

64. Fanin, N.; Hättenschwiler, S.; Schimann, H.; Fromin, N. Interactive effects of C, N and P fertilization on soil microbial community structure and function in an Amazonian rain forest. Funct. Ecol. 2015, 29, 140-150. [CrossRef]

65. Camenzind, T.; Hättenschwiler, S.; Treseder, K.; Lehmann, A.; Rillig, M.C. Nutrient limitation of soil microbial processes in tropical forests. Ecol. Monogr. 2018, 88, 2-21. [CrossRef]

66. Giller, K.E. Nitrogen Fixation in Tropical Cropping Systems; CABI: Wallingford, UK, 2001.

67. Bottomley, P.J.; Myrold, D.D. Biological N inputs. In Soil Microbiology, Ecology, and Biochemistry, 4th ed.; Paul, E.A., Ed.; Academic Press: London, UK, 2015; pp. 447-470.

68. Kamble, P.N.; Gaikwad, V.B.; Kuchekar, S.R.; Bååth, E. Microbial growth, biomass, community structure and nutrient limitation in high $\mathrm{pH}$ and salinity soils from Pravaranagar (India). Eur. J. Soil Biol. 2014, 65, 87-95. [CrossRef]

69. Yang, P.X.; Ma, L.; Chen, M.H.; Xi, J.Q.; He, F.; Duan, C.-Q.; Mo, M.H.; Fang, D.H.; Duan, Y.Q.; Yang, F.-X. Phosphate solubilizing ability and phylogenetic diversity of bacteria from P-rich soils around Dianchi Lake drainage area of China. Pedosphere 2012, 22, 707-716. [CrossRef]

70. Goberna, M.; Navarro-Cano, J.A.; Valiente-Banuet, A.; García, C.; Verdú, M. Abiotic stress tolerance and competition-related traits underlie phylogenetic clustering in soil bacterial communities. Ecol. Lett. 2014, 17, 191-201. [CrossRef] [PubMed]

71. Filippidou, S.; Wunderlin, T.; Junier, T.; Jeanneret, N.; Dorador, C.; Molina, V.; Johnson, D.R.; Junier, P. A combination of extreme environmental conditions favor the prevalence of endospore-forming Firmicutes. Front. Microbiol. 2016, 7, 01707. [CrossRef]

72. Manzoni, S.; Schimel, J.P.; Porporato, A. Responses of soil microbial communities to water stress: Results from a meta-analysis. Ecology 2012, 93, 930-938. [CrossRef] [PubMed]

73. Rousk, J.; Bååth, E. Fungal and bacterial growth in soil with plant materials of different C/N ratios. FEMS Microbiol. Ecol. 2007, 62, 258-267. [CrossRef]

74. Kamble, P.N.; Bååth, E. Carbon and nitrogen amendments lead to differential growth of bacterial and fungal communities in a high-pH soil. Pedosphere 2018, 28, 255-260. [CrossRef]

75. Wanzek, T.; Keiluweit, M.; Baham, J.; Dragila, M.I.; Fendorf, S.; Fiedler, S.; Nico, P.S.; Kleber, M. Quantifying biogeochemical heterogeneity in soil systems. Geoderma 2018, 324, 89-97. [CrossRef]

76. Delgado-Baquerizo, M.; Maestre, F.; Gallardo, A.; Bowker, M.A.; Wallenstein, M.D.; Quero, J.L.; Ochoa, V.; Gozalo, B.; GarcíaGómez, M.; Soliveres, S.; et al. Decoupling of soil nutrient cycles as a function of aridity in global drylands. Nature 2013, 502, 672-676. [CrossRef] [PubMed]

77. Montecchia, M.S.; Tosi, M.; Soria, M.A.; Vogrig, J.A.; Sydorenko, O.; Correa, O.S. Pyrosequencing reveals changes in soil bacterial communities after conversion of Yungas forests to agriculture. PLoS ONE 2015, 10, e0119426. [CrossRef] [PubMed]

78. Trivedi, P.; Delgado-Baquerizo, M.; Anderson, I.C.; Singh, B.K. Response of soil properties and microbial communities to agriculture: Implications for primary productivity and soil health indicators. Front. Plant Sci. 2016, 7, 990. [CrossRef] 
79. Wang, S.; Li, T.; Zheng, Z.; Chen, H.Y.H. Soil aggregate-associated bacterial metabolic activity and community structure in different aged tea plantations. Sci. Total Environ. 2019, 654, 1023-1032. [CrossRef] [PubMed]

80. Su, X.; Su, X.; Yang, S.; Zhou, G.; Ni, M.; Wang, C.; Qin, H.; Zhou, X.; Deng, J. Drought changed soil organic carbon composition and bacterial carbon metabolizing patterns in a subtropical evergreen forest. Sci. Total Environ. 2020, 736, 139568. [CrossRef]

81. Barnard, R.L.; Osborne, C.A.; Firestone, M.K. Responses of soil bacterial and fungal communities to extreme desiccation and rewetting. ISME J. 2013, 7, 2229-2241. [CrossRef] [PubMed]

82. Meisner, A.; Bååth, E.; Rousk, J. Microbial growth responses upon rewetting soil dried for four days or one year. Soil Biol. Biochem. 2013, 66, 188-192. [CrossRef]

83. Meisner, A.; Jacquiod, S.; Snoek, B.L.; ten Hooven, F.C.; van der Putten, W.H. Drought legacy effects on the composition of soil fungal and prokaryote communities. Front. Microbiol. 2018, 9, 294. [CrossRef]

84. Hueso, S.; Hernández, T.; García, C. Resistance and resilience of the soil microbial biomass to severe drought in semiarid soils: The importance of organic amendments. Appl. Soil Ecol. 2011, 50, 27-36. [CrossRef]

85. Bouskill, N.J.; Wood, T.E.; Baran, R.; Ye, Z.; Bowen, B.P.; Lim, H.C.; Zhou, J.; van Nostrand, J.D.; Nico, P.; Northen, T.R.; et al. Belowground response to drought in a tropical forest soil. I. Changes in microbial functional potential and metabolism. Front. Microbiol. 2016, 7, 525. [CrossRef]

86. Fierer, N.; Leff, J.W.; Adams, B.J.; Nielsen, U.N.; Bates, S.T.; Lauber, C.L.; Owens, S.; Gilbert, J.A.; Wall, D.H.; Caporaso, J.G. Cross-biome metagenomic analyses of soil microbial communities and their functional attributes. Proc. Natl. Acad. Sci. USA 2012, 109, 21390-21395. [CrossRef] [PubMed]

87. Fierer, N.; Bradford, M.A.; Jackson, R.B. Toward an ecological classification of soil bacteria. Ecology 2007, 88, 1354-1364. [CrossRef] [PubMed]

88. Naylor, D.; Coleman-Derr, D. Drought stress and root-associated bacterial communities. Front. Plant Sci. 2018, 8, 2223. [CrossRef]

89. Austin, A.T.; Yahdjian, L.; Stark, J.M.; Belnap, J.; Porporato, A.; Norton, U.; Ravetta, D.A.; Schaeffer, S.M. Water pulses and biogeochemical cycles in arid and semiarid ecosystems. Oecologia 2004, 141, 221-235. [CrossRef]

90. Potts, M. Desiccation tolerance of prokaryotes. Microbiol. Rev. 1994, 58, 755-805. [CrossRef] [PubMed]

91. Felsmann, K.; Baudis, M.; Gimbel, K.; Kayler, Z.E.; Ellerbrock, R.; Bruehlheide, H.; Bruckhoff, J.; Welk, E.; Puhlmann, H.; Weiler, M. Soil bacterial community structure responses to precipitation reduction and forest management in forest ecosystems across Germany. PLoS ONE 2015, 10, e0122539.

92. Castro, H.F.; Classen, A.T.; Austin, E.E.; Norby, R.J.; Schadt, C.W. Soil microbial community responses to multiple experimental climate change drivers. Appl. Environ. Microbiol. 2010, 76, 999-1007. [CrossRef]

93. Neilson, J.W.; Califf, K.; Cardona, C.; Copeland, A.; van Treuren, W.; Josephson, K.L.; Knight, R.; Gilbert, J.A.; Quade, J.; Caporaso, J.G. Significant impacts of increasing aridity on the arid soil microbiome. mSystems 2017, 2, e00195-16. [CrossRef]

94. Philippot, L.; Andersson, S.G.E.; Battin, T.J.; Prosser, J.I.; Schimel, J.P.; Whitman, W.B.; Hallin, S. The ecological coherence of high bacterial taxonomic ranks. Nat. Rev. Microbiol. 2010, 8, 523-529. [CrossRef]

95. Lynch, M.D.; Neufeld, J.D. Ecology and exploration of the rare biosphere. Nat. Rev. Microbiol. 2015, 13, 217-229. [CrossRef]

96. Pedrós-Alió, C. The rare bacteria biosphere. Annu. Rev. Mar. Sci. 2012, 4, 449-466. [CrossRef] [PubMed]

97. Kurm, V.; van der Putten, W.H.; de Boer, W.; Naus-Wiezer, S.; Hol, W.H.G. Low abundant soil bacterial can be metabolically versatile and fast growing. Ecology 2017, 98, 555-564. [CrossRef]

98. Soliveres, S.; Manning, P.; Prati, D.; Gossner, M.M.; Alt, F.; Arndt, H.; Baumgartner, V.; Binkenstein, J.; Birkhofer, K.; Blaser, S.; et al. Locally rare species influence grassland ecosystem multifunctionality. Philos. Trans. R. Soc. B 2016, 371, 20150269. [CrossRef]

99. Campo, J.; Merino, A. Variations in soil carbon sequestration and their determinants along a precipitation gradient in seasonally dry tropical forests. Glob. Chang. Biol. 2016, 22, 1942-1956. [CrossRef] [PubMed]

100. Paul, E.A. Soil Microbiology, Ecology, and Biochemistry, 4th ed.; Academic Press: London, UK, 2015.

101. Taylor, D.L.; Sinsabaugh, R.L. The soil fungi: Occurrence, phylogeny, and ecology. In Soil Microbiology, Ecology, and Biochemistry, 4th ed.; Paul, E.A., Ed.; Academic Press: London, UK, 2015; pp. 77-109.

102. Da Silva, L.L.; Veloso, T.G.R.; Manhaes, J.H.C.; da Silva, C.C.; de Queiroz, M.V. The plant organs and rhizosphere determine the common bean mycobiome. Braz. J. Microbiol. 2020, 51, 765-772. [CrossRef] [PubMed] 